\title{
Suppressive Effects of Hydroxytyrosol on Oxidative Stress and Nuclear Factor- $K B$ Activation in THP-1 Cells
}

\author{
Xiaomei Zhang, ${ }^{a, b}$ Jun CAO, ${ }^{b}$ Liping JIANG, ${ }^{c}$ and Laifu Zhong ${ }^{*}, b$ \\ ${ }^{a}$ Department of Laboratory Medicine, College of Medicine, Dalian University; Dalian 116622, Liaoning, P. R. China: \\ ${ }^{b}$ Department of Toxicology, Dalian Medical University; 9 Lushunnan Road, Dalian 116044, Liaoning, P. R. China: and \\ ${ }^{c}$ China-Japanese Joint Institute for Medical and Phamaceutical Science, Dalian Medical University; 465 Zhongshan \\ Road, Dalian 116027, Liaoning, P. R. China.
}

Received October 30, 2008; accepted December 4, 2008; published online January 5, 2009

\begin{abstract}
This study was designed to investigate whether hydroxytyrosol (HT) may ameliorate oxidative stress and nuclear factor kappaB (NF- $\kappa$ B) activation in the lipopolysaccharide (LPS)-stimulated THP-1 cell line. We measured the intracellular reactive oxygen species (ROS) formation using 2,7-dichlorofluorescein diacetate (DCFHDA) as a fluorescent probe. Intracellular glutathione (GSH) level was estimated by fluorometric methods. Nitric oxide (NO) production was measured as nitrite (a stable metabolite of NO) concentrations using the Griess reagent system following Jiancheng Institute of Biotechnology protocols. To study the effect of HT on LPSinduced NF- $\kappa$ B activation in THP-1 cells, Western blot analysis of the nuclear fraction of cell lysates was performed. The results showed that treatment of THP-1 cells with HT significantly reduced LPS-stimulated NO production and ROS formation in a concentration-dependent manner. HT at 50 and $100 \mu_{\mathrm{M}}$ concentrations increased the GSH level. The specific DNA-binding activities of NF- $\kappa$ B on nuclear extracts from 50 and $100 \mu \mathrm{M}$ HT treatments were significantly suppressed. The antioxidant $N$-acetylcysteine (NAC) also showed the same effects as HT on LPS-induced ROS and NO generation, change of GSH level, and NF- $\kappa$ B activation. These findings suggest that HT has antioxidant activity to suppress intracellular oxidative stress and NF- $\kappa \mathrm{B}$ activation in THP-1 cells.
\end{abstract}

Key words hydroxytyrosol; THP-1 cell; oxidative stress; nuclear factor kappaB

Recent publications have shown that an oxidized cytosolic environment amplifies activation of nuclear factor kappaB $(\mathrm{NF}-\kappa \mathrm{B})$, which plays a critical role during inflammatory processes by activating many genes encoding for proinflammatory cytokines and immunoregulatory mediators. ${ }^{1)}$ Some publications have also suggested that reactive oxygen species (ROS) influence inflammatory processes through mechanisms that are dependent on NF- $\kappa \mathrm{B} .{ }^{2)}$ In the course of many inflammatory diseases reduced levels of glutathione (GSH) and/or increased levels of free radicals have been detected, ${ }^{3,4)}$ indicating the involvement of oxidative stress.

Hydroxytyrosol (HT), present in the phenolic fraction of virgin olive oil in a concentration range of $10-300 \mathrm{ppm}$, is abundant in naturally fermented table olives and can be also recovered from virgin olive oil by-products. ${ }^{5)}$ At nutritionally relevant concentrations, HT possesses marked antioxidant activity and is a good radical scavenger. ${ }^{6,7)}$ HT in vitro prevents protein damage in melanoma cells by ROS induced by long-wave ultraviolet light ${ }^{8)}$ and DNA damage in Jurkat cells exposed to hydrogen peroxide $\left(\mathrm{H}_{2} \mathrm{O}_{2}\right){ }^{9)}$ Preincubation of intestinal Caco-2 cells with HT prevents the typical damages of oxidative stress. ${ }^{10)}$ Similarly, HT exerts protective effects against $\mathrm{H}_{2} \mathrm{O}_{2}$-induced oxidative hemolysis and malondialdehyde (MDA) formation in red blood cells. ${ }^{11)}$ It also exerts inhibitory effects on GSH depletion induced by tert-butylhydroperoxide ( $t$-BHP) in HepG2 cells. ${ }^{12)}$ However, little information is available about the effects of HT on oxidative stress and NF- $\kappa$ B activation in LPS-stimulated THP- 1 cells. In this study we assessed supression by HT of nitric oxide (NO), ROS, NF- $\kappa \mathrm{B}$ activation, and the increase of GSH contents in lipopolysaccharide (LPS)-stimulated THP-1 cells.

\section{MATERIALS AND METHODS}

Chemicals The sample of HT was supplied by Eisai Food \& Chemical Co., Ltd., Japan. LPS (Escherichia coli LPS, serotype 0127:B8), and 2',7'-dichlorofluorescein diacetate (DCFH-DA) were purchased from Sigma (St. Louis, MO, U.S.A.).

Cell Culture and Treatment Human monocytic THP-1 cells (American Type Culture Collection, Manassas, VA, U.S.A.) were obtained from Peking Union Medical College (Peking, China) and cultured in RPMI 1640 medium supplemented with 10\% fetal bovine serum (Gibco), penicillin $(100 \mathrm{U} / \mathrm{ml}$; Gibco), and streptomycin $(100 \mathrm{mg} / \mathrm{ml}$; Gibco $)$ at $37{ }^{\circ} \mathrm{C}$ in a $5 \% \mathrm{CO}_{2}$-humidified incubator. The cells were treated with or without the indicated concentrations of HT $(25,50,100 \mu \mathrm{M})$ or $N$-acetylcysteine (NAC) $(2.5 \mathrm{~mm})$ for $10 \mathrm{~min}$ then incubated with LPS $(1.0 \mu \mathrm{g} / \mathrm{ml})$ for $3 \mathrm{~h}$.

Measurement of ROS Intracellular ROS production was measured using DCFH-DA by the method of Bass and coworkers, ${ }^{13)}$ with some modification. DCFH-DA penetrates the cells and is hydrolyzed by intracellular esterases to the nonfluorescent DCFH, which can be rapidly oxidized to the highly fluorescent 2,7-dichlorofluorescein (DCF) in the presence of ROS. THP-1 monocytes were inoculated into sixwell plates; the numbers of cells were $2 \times 10^{5}$ cells/well. After incubation, cell counts of living and dead cells were examined by trypan blue staining and cell viability was calculated. Cells were washed twice with cold PBS and then suspended in PBS, and incubated with DCFH-DA at a final concentration of $5 \mu \mathrm{M}$ at $37^{\circ} \mathrm{C}$ in the dark for an additional $40 \mathrm{~min}$. The fluorescent intensity of the cell suspensions was then monitored by a fluorescence spectrophotometer (HITACHI 650-60, Tokyo, Japan, excitation wavelength $485 \mathrm{~nm}$, emis- 
sion wavelength $530 \mathrm{~nm}$ ).

Measurement of NO Nitric oxide (NO) production was measured as nitrite (a stable metabolite of NO) concentrations using the Griess reagent system following Jiancheng Institute of Biotechnology protocols (Jiancheng Institute of Biotechnology, Nanjing, China). The fluorogenic substrate of 2,3-diaminonaphthalene (DAN) can be changed into the fluorescent 1-(H)-naphothiazolei with $\mathrm{NO}_{2}^{-}$under the acid solution. Cells were washed twice with cold PBS and then suspended in $1 \mathrm{ml}$ PBS, and incubated with $10 \mu \mathrm{l}$ of DAN at a concentration of $0.5 \mathrm{mg} / \mathrm{ml}$ at $37^{\circ} \mathrm{C}$ in the dark for an additional $40 \mathrm{~min}$. After incubation, $50 \mu \mathrm{l}$ of $2.8 \mathrm{~N} \mathrm{NaOH}$ was added to terminate the reaction. The fluorescent intensity of the cell suspensions was then monitored by fluorescence spectrophotometer (HITACHI 650-60, Tokyo, Japan, excitation wavelength $365 \mathrm{~nm}$, emission wavelength $450 \mathrm{~nm}$ ).

Measurement of Intracellular GSH Reduced GSH was assayed using a modified method of Hissin and Hilf. ${ }^{14)}$ THP1 monocytes were inoculated into six-well plates; the numbers of cells were $2 \times 10^{5}$ cells/well. After incubation, cell counts of living and dead cells were examined by trypan blue staining and cell viability was calculated. The medium was discarded and $0.4 \mathrm{ml}$ of $5 \%$ trichloroacetic acid (TCA) was added. After $30 \mathrm{~min}$ of incubation at $4{ }^{\circ} \mathrm{C}$ to extract $\mathrm{GSH}$, $50 \mathrm{ml}$ of the TCA extract was added to tubes containing 1 $\mathrm{mg} / \mathrm{ml} \mathrm{o}$-phthalaldehyde $(1 \mathrm{ml})$ in $50 \mathrm{mmol} / 1$ phosphate $/ 5$ mmol/1 EDTA buffer ( $\mathrm{pH} 8.0)$. The tubes were incubated at $37^{\circ} \mathrm{C}$ in the dark $(15 \mathrm{~min})$. Fluorescence was measured by fluorescence spectrophotometer (HITACHI 650-60, Tokyo, Japan). Excitation and emission wavelengths were 485 and $550 \mathrm{~nm}$, respectively. The concentration of GSH was determined from a GSH standard.

Preparation of Nuclear Extracts and Western Blot Analysis Nuclear extracts were obtained as described previously. ${ }^{15)}$ Briefly, cells $\left(5 \times 10^{6}\right.$ cells $\left./ \mathrm{ml}\right)$ were lysed in icecold buffer A (10 mM HEPES, pH 7.9, $10 \mathrm{~mm} \mathrm{KCl,} 0.1 \mathrm{~mm}$ EDTA, 0.1 mM EGTA, $1 \mathrm{~mm}$ dithiotreitol, and $0.5 \mathrm{~mm}$ PMSF) and after $15 \mathrm{~min}$ incubation on ice, NP-40 was added to a final concentration of $0.5 \%(\mathrm{v} / \mathrm{v})$. Nuclei were collected by centrifugation. Nuclear pellet was suspended in ice-cold buffer C (20 mм HEPES, pH 7.9, 400 mm NaCl, 1 mм EGTA, $1 \mathrm{~mm}$ dithiotreitol, $1 \mathrm{~mm}$ PMSF, $1 \mu \mathrm{g} / \mathrm{ml}$ pepstatin, $1 \mu \mathrm{g} / \mathrm{ml}$ leupepin, and $20 \%, \mathrm{v} / \mathrm{v}$ glycerol) and incubated for $30 \mathrm{~min}$. Nuclear proteins were collected in supernatant after centrifugation $\left(12000 \times \mathbf{g} ; 4^{\circ} \mathrm{C} 10 \mathrm{~min}\right)$. The total protein content in the nuclear extracts was determined by the method of Bradford (Bradford et al. 1976).

Statistical Analysis Data are presented as means \pm standard deviation (S.D.). The statistical significance of differences among groups was assessed by one-way analysis of variance (ANOVA), followed by least significant difference (LSD) for multiple comparison, as a post hoc test. The level of significance was set at $p<0.05$ and 0.01 for all statistical analysis.

\section{RESULTS}

Effect of HT on Intracellular ROS Level in LPS-Stimulated THP-1 Cells The concentration of intracellular ROS was evaluated by the changes of DCF fluorescence intensity. Figure 1 shows a dose-dependent reduction of the intracellu-

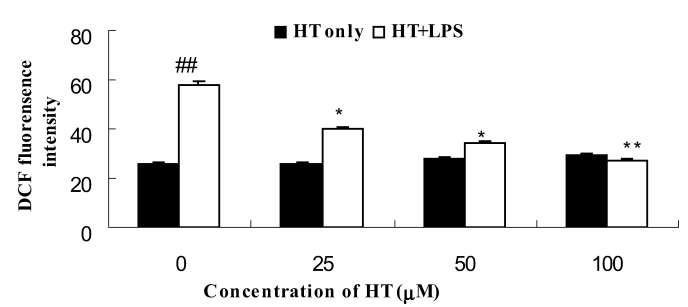

Fig. 1. Effect of HT on ROS Level in THP-1 Cells Stimulated by LPS

Results are expressed as fluorescence units. Each bar represents mean \pm S.D. of three independent experiments $(n=3) . * p<0.05, * * p<0.01 v s$. the group treated with LPS only. $p<0.01 v s$. cells without LPS and HT.

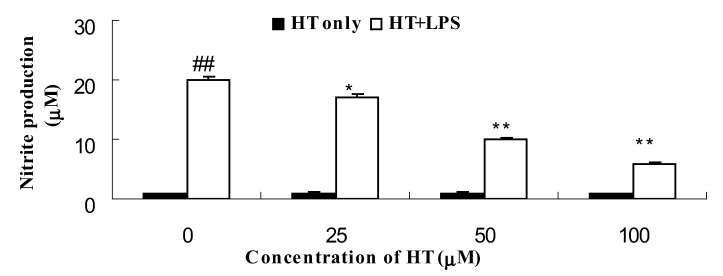

Fig. 2. Effect of HT on NO Level in THP-1 Cells Stimulated by LPS

Each bar represents mean \pm S.D. of three independent experiments $(n=3)$. $* p<0.05$, $* * p<0.01 v s$. the group treated with LPS only. \# $p<0.01 v s$. cells without LPS and HT.

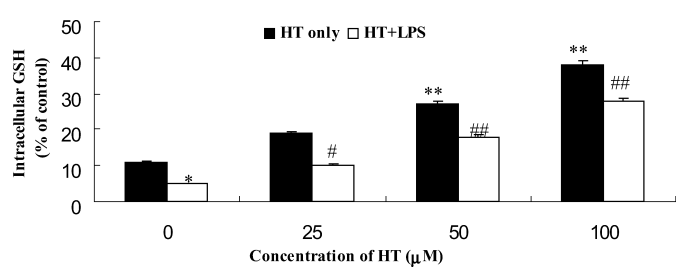

Fig. 3. Effect of HT on GSH Level in THP-1 Cells Stimulated by LPS

Data are mean \pm S.D. of three independent experiment $(n=3) . * p<0.05, * * p<0.01$ $v s$. cells exposed to $0 \mu_{\mathrm{M}} \mathrm{HT}$; \# $p<0.01$, vs. cells exposed to LPS only.

lar ROS level in LPS-stimulated THP-1 cells by HT. DCF fluorescence intensity dropped significantly from $58 \pm 3$ in cells treated with LPS only to values between $40 \pm 1(p<0.05)$ and $27 \pm 2(p<0.01)$ in cells to which 25 and $100 \mu \mathrm{M}$ HT was added.

Effects of HT on NO Production in LPS-Stimulated THP-1 Cells Nitrite was used as an indicator of NO production, due to the short half-life of NO. The nitrite concentration in cortical tissue homogenates was significantly increased in the LPS only-treated group. As shown in Fig. 2, all three doses of HT treatment significantly suppressed the increase of NO formation $(p<0.05$ or $p<0.01)$.

Effect of HT on the LPS-Induced GSH in THP-1 Cells GSH is an important cellular antioxidant. To determine the effect of HT on the redox status of cells induced by LPS, GSH level was evaluated in the cells treated with LPS. GSH decreased dramatically when the cells were treated with 1 $\mu \mathrm{g} / \mathrm{ml}$ LPS. When pretreated with all doses of HT, GSH depletion was greatly prevented in the cells treated with $1 \mu \mathrm{g} /$ ml LPS (Fig. 3).

Effects of HT on LPS-Induced NF- $\kappa$ B Activation in THP-1 Cells To study the effect of HT on LPS-induced NF- $\kappa$ B activation in THP-1 cells, Western blot analysis of the nuclear fraction of cell lysates was performed. As shown in Fig. 4, the translocation of NF- $\kappa \mathrm{B}$ in the nuclear fractions of THP-1 cells was increased by treatment with LPS $(1 \mu \mathrm{g} /$ 
$\mathrm{ml}$ ). However, pretreatment of THP-1 cells with HT attenuated LPS-induced nuclear NF- $\kappa$ B expression by THP- 1 cells in a dose-dependent manner (Fig. 4).

Effects of NAC on the LPS-Induced ROS, NO, GSH, and NF- $\boldsymbol{K}$ B Activation in THP-1 Cells Because ROS have been viewed previously as general messengers for signal-induced NF- $\kappa$ B activation, ${ }^{16,17)}$ in this study to examine the exact inhibitory mechanism of HT on NF- $\kappa \mathrm{B}$ activation, we used NAC, a major precursor of GSH and an antioxidant, as positive control to investigate the role of HT in modulation of redox status and NF- $\kappa$ B. Similar to the effect of HT administration, addition of NAC also greatly blocked LPSinduced NF- $\kappa$ B activation and decreased LPS-stimulated intracellular generation of ROS and NO, and dramatically blocked LPS-induced GSH decrease.

\section{DISCUSSION}

On the basis of previous literature and the current results, it is apparent that the inflammatory response of LPS in macrophages includes initial induction of ROS, which leads to activation of $\mathrm{NF}-\kappa \mathrm{B}$ and to induction of inducible nitric oxide synthase (iNOS) and inflammatory cytokines. This last step would lead to the production of NO in toxic amounts, together with toxic cytokines. Early works demonstrated that HT possesses marked antioxidant activity and is a good radical scavenger. ${ }^{18)}$ HT in vitro prevents LDL oxidation ${ }^{19)}$ and platelet aggregation $^{20)}$ and inhibits 5- and 12-lipoxygenase. ${ }^{21)}$

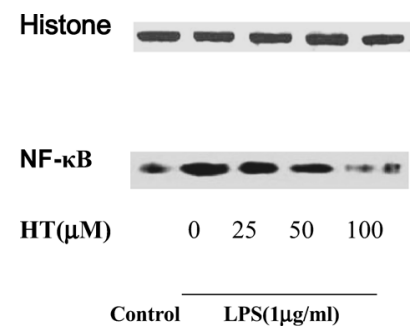

Fig. 4. Representative Western Blot Analysis Demonstrating Effect of Concentration-Dependent HT on LPS-Induced NF- $\kappa$ B p 65 Translocation in the Nuclear Fraction of THP-1 Cells
A recent report indicates that HT and other phenolic antioxidants reduce vascular cell adhesion molecule-1 mRNA expression by blocking activation of transcription factors NF$\kappa \mathrm{B}$ and activator protein-1. ${ }^{22)}$ However little information is available about the effect of HT on the oxidative stress and NF- $\kappa$ B activation in LPS-stimulated THP-1 cells. The present study was performed to examine the suppression by HT of ROS, NO, and NF- $\kappa \mathrm{B}$ activation and the increase of GSH in LPS-stimulated THP-1 cells.

LPS is a potent stimulator of $\mathrm{NO}^{23,24)} \mathrm{NO}$ is involved in phagocytosis at the physiological level, but also can lead to amplification of inflammation and tissue injury when produced in large amounts. NO reacts rapidly with superoxide to form peroxynitrite, a powerful oxidant that damages many biological molecules including $\mathrm{DNA}^{25,26)}$ and upregulates the DNA-binding activity of NF- $\kappa \mathrm{B}$ in macrophages activated with inflammatory stimulants. ${ }^{27,28)}$ In the present study, we found that LPS treatment to cells significantly elevated NO generation by more than the LPS-untreated negative control, which has been documented by several researchers. ${ }^{28)}$ Pretreatment with HT could decrease the level of NO induced by LPS. Futhermore, pretreatment with NAC has also the same effect as HT. LPS stimulation has been shown to increase ROS in monocytes/macrophages. ${ }^{29)}$ ROS are key components of postreceptor intracellular signaling pathways, ${ }^{30)}$ and activation of the NF- $\kappa \mathrm{B}$ and MAPK pathways plays a key role in mediating macrophage responses to proinflammatory stimuli, such as LPS and cytokines. ${ }^{31-33)}$ In another aspect, considerable experimental evidence has been adduced in support of protection of HT against cytotoxicity induced by ROS in different cell systems. ${ }^{8,9)}$ Our present study showed that the intracellular ROS level was significantly increased in THP-1 cells stimulated by LPS. Pretreatment with all three doses of HT and NAC reduced the generation of ROS induced by LPS, achieving a maximum value of $100 \%$ reduction in DCF fluorescence intensity.

Our findings show that the decrease of GSH by LPS alone is consistent with those of Paromov et $a .^{34)}$ and Wang et $a{ }^{35)}$ Kaur et al. ${ }^{36)}$ also reported that TBARS levels were significantly increased, whereas GSH and SOD levels
A

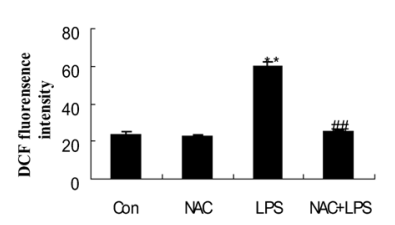

$\mathrm{C}$

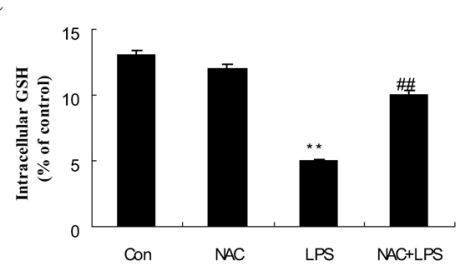

B

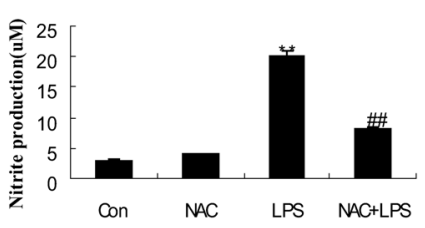

D

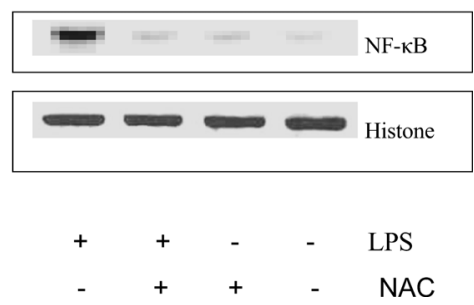

Fig. 5. Effect of NAC on ROS Level (A), NO Level (B), GSH Level (C), and NF- $\kappa$ B Activation (D) in THP-1 Cells Stimulated by LPS Data are mean \pm S.D. of three independent experiments $(n=3) . * * p<0.01 v$ s. control, $\# p<0.01 v$ s. cells exposed to LPS only. 
decreased in the liver homogenates of LPS-challenged rats. Depletion of intracellular stores of GSH plays an important role in protecting against oxidative stress by reacting directly with $\mathrm{ROS}^{37-39)}$ and $\mathrm{NO}^{40)}$ Moreover, pretreatment with HT significantly restores the GSH level reduced by $t$-BHP treatment in HepG2 cells. ${ }^{12)}$ In our experimental conditions, stimulation of THP- 1 cells with LPS $1 \mu \mathrm{g} / \mathrm{ml}$ induced a dramatic decrease in the concentration of GSH, which was prevented by pretreatment with all three doses of HT. Pretreatment with NAC also prevented the decrease of GSH induced by LPS.

$\mathrm{NF}-\kappa \mathrm{B}$ is a critical signal molecule for inflammatory processes and a ubiquitously expressed multiunit transcription factor that is activated by diverse signals, possibly via phosphorylation of the I- $\kappa \mathrm{B}$ subunit and its dissociation from the inactive cytoplasmic complex, followed by translocation of the active dimer, p50 and p65, to the nucleus. ${ }^{41,42)}$ Recent reviews show that NF- $\kappa \mathrm{B}$ activation is extremely sensitive to cellular redox status and plays a key role in the pathogenesis of inflammatory diseases, as exemplified in rheumatoid arthritis and vascular diseases. ${ }^{43,44)}$ During inflammatory processes, activation of NF- $\kappa \mathrm{B}$ plays a crucial role since it is responsible for the activation of inflammatory genes that encode for cytokine production. Although the exact regulatory mechanisms of NF- $\kappa \mathrm{B}$ activation and inhibition are still unknown, there is no doubt that the redox potential has a strong impact in this regard. Redox homeostasis plays a critical role in protection of cells from both internal and external oxidative and other forms of stresses, and maintains a regulatory role of redox-sensitive transcription factors such as NF$\kappa \mathrm{B} .{ }^{45,46)}$ It has also been shown that NF- $\kappa \mathrm{B}$ nuclear translocation is induced by ROS. ${ }^{47}$ By contrast antioxidants such NAC, which reduce cytosolic redox potential, are able to diminish NF- $\kappa \mathrm{B}$ activation. ${ }^{48)}$ We previously reported that treatment of THP- 1 cells with LPS $1 \mu \mathrm{g} / \mathrm{ml}$ induced NF- $\kappa \mathrm{B}$ activation, which was prevented by pretreatment with HT 50 and $100 \mu \mathrm{M}$ and NAC. The inhibitory effect of HT on NF- $\kappa \mathrm{B}$ activation was consistent with of the reports of Maiuri et $a l .{ }^{49)}$ Indeed, the suppressive effect of LPS to NF- $\kappa \mathrm{B}$ activation at HT 50 and $100 \mu \mathrm{M}$ and NAC coincides with attenuated NO and ROS generation and elevated GSH content. Previous studies also observed antioxidant activity of HT. Futhermore, it has been reported that carnosol, an antioxidant in rosemary, can specifically prevent activation of NF$\kappa \mathrm{B}$ by LPS in RAW 264.7 cells. ${ }^{50)}$ From the above discussion, we conclude that HT could inhibit NF- $\kappa \mathrm{B}$ activation through decreasing ROS, ande NO and preventing the decreases of GSH induced by LPS in THP-1 cells. In summary, HT may attenuate intracellular oxidative stress by direct scavenging of $\mathrm{NO}$ and ROS, and by delaying consumption of $\mathrm{GSH}$, which results in suppression of NF- $\kappa \mathrm{B}$ activation.

Acknowledgements The authors are grateful to Shuxian Qu and Haibo Cheng in the Central Laboratory of Dalian Medical University for instrumental assistance.

\section{REFERENCES}

1) Morel Y., Barouki R., Biochem. J., 342, 481-496 (1999).

2) Schulze-Osthoff K., Los M., Baeuerle P. A., Biochem. Pharmacol., 50, 735-741 (1995).

3) Macdonald J., Galley H. F., Webster N. R., Br. Anaesth., 90, 221-232
(2003).

4) Exner R., Wessner B., Manhart N., Roth E., Wiener klinische Wochenschrift, 112, 610-616 (2000).

5) Boskou D., “Olive Oil Composition,” ed. by Boskou D., AOCS, Champaign, 1996, pp. 52-83.

6) De la Puerta R., Ruiz Gutierrez V., Hoult J. R. S., Biochem. Pharmacol., 57, 445-449 (1999).

7) Manna C., Galletti P., Cucciola V., Montedoro G., Zappia V., J. Nutr. Biochem., 10, 159-165 (1999).

8) Stefania D. A., Diego I., Valentina M., Alvara S., Giovanna D., Adone B., Lucia M., Maria A. T., Marcello Z., Patrizia G., Free Biol. Med., 38, 908-919 (2005).

9) Lambros N., Paschalis T. D., Nektarios A., Dimitrios B., Apostolos A., Dimitrios G., Free Radic. Res., 39, 787-795 (2005).

10) Manna C., Galletti P., Cucciolla V., Moltedo O., Leone A., Zappia V., J. Nutr., 127, 286-292 (1997).

11) Manna C., Galletti P., Cucciolla V., Montedoro G., Zappia V., J. Nutr. Biochem., 10, 159-165 (1996).

12) Goya L., Mateos R., Bravo L., Eur. J. Nutr., 46, 70_78 (2007).

13) Bass D. A., Parce J. W., Dechatelet L. R., Szejda P., Seeds M. C., Thomas M., J. Immunol., 130, 1910-1917 (1983).

14) Hissin P. J., Hilf R., Anal. Biochem., 74, 214-26 (1976).

15) Dignam J. D., Lebovita R. M., Roeder R. G., Nucleic Acids Res., 5, 1475-1489 (1983).

16) Wang S., Kotamraju S., Konorev E., Kalivendi S., Joseph J., Kalyanaraman B., Biochem. J., 367, 729-740 (2002).

17) Schulze-Osthoff K., Los M., Baeuerle P. A., Biochem. Pharmacol., 50, 735-741 (1995).

18) Deiana M., Aruoma O. I., Bianchi M. D. L. P., Spencer J. P. E., Kaur H., Halliwell B., Aeschbach R., Banni S., Dessi M. A., Corongiu F. P., Free Radic. Biol. Med., 26, $762-769$ (1999).

19) Salami M., Galli C., De Angelis L., Visioli F., Pharmacol. Res., 31, 275-279 (1995).

20) Petroni A., Blasevich M., Salami M., Papini N., Montedoro G., Galli G., Thromb. Res., 78, 151-160 (1995).

21) Kohyama N., Nagata T., Fujimoto S., Sekiya K., Biosci. Biotechnol. Biochem., 61, 347-350 (1997).

22) Choi C., Cho H., Park J., Cho C., Song Y., Biosci. Biotechnol. Biochem., 67, 1916-1922 (2003).

23) Tsuji K., Kwon A. H., Yoshida H., Qiu Z., Kaibori M., Okumura T., Kamiyama Y., J. Hepatol., 42, 94-101 (2005).

24) Hayashi Y., Abe M., Murai A., Shimizu N., Okamoto I., Katsuragi T., Tanaka K., Microbiol. Immunol., 49, 139-147 (2005).

25) Yen G. C., Lai H. H., Food Chem. Toxicol., 40, 1433-1440 (2002).

26) Miautani K., Ikeda K., Nishikata T., Yamori Y., J. Hypertens., 18, 1833 - 1840 (2000).

27) Ippouchi K., Itou H., Azuma K., Higashio H., Life Sci., 71, 411-419 (2002).

28) Kang I. L., Lee K., Castranova V., Mol. Cell. Biochem., 215, 1-9 (2000).

29) Sanlioglu S., Williams C. M., Samavati L., Butler N. S., Wang G., McCray P. B., Ritchie T. C., Hunninghake G. W., Zandi E., Engelhardt J. F., J. Biol. Chem., 276, 30188-30198 (2001).

30) DeYulia G. J. Jr., Carcamo J. M., Borquez-Ojeda O., Shelton C. C., Golde D. W.. Proc. Natl. Acad. Sci. U.S.A., 102, 5044-5049 (2005).

31) Hwang D., Jang B. C., Yu G., Boudreau M., Biochem. Pharmacol., 54, 87-96 (1997).

32) Mestre J. R., Mackrell P. J., Rivadeneira D. E., Stapleton P. P., Tanabe T., Daly J. M., J. Biol. Chem., 276, 3977-3982 (2000).

33) Kang S. W., Chang T. S., Lee T. H., Kim E. S., Yu D. Y., Rhee S. G., J. Biol. Chem., 279, 2535-2543 (2004).

34) Paromov V., Qui M., Yang H., Smith M., Stone W. L., BMC Cell Biol., 20, 9-33 (2008).

35) Wang H., Xu D. X., Lu J. W., Zhao L., Zhang C., Wei W., Acta Pharmacol. Sinica, 28, 1803-1809 (2007).

36) Kaur G., Tirkey N., Bharrhan S., Chanana V., Rishi P., Chopra K., Clin. Exp. Immunol., 145, 313-321 (2006).

37) Elsayed N. M., Omaye S. T., Toxicology, 199, 195-206 (2004).

38) Han S., Espinoza L. A., Liao H., Boulares A. H., Smulson M. E., Br. J. Pharmacol., 141, 795-802 (2004)

39) Kadar T., Turetz J., Fishbine E., Sahar R., Chapman S., Amir A., Curr. Eye Res., 22, 42-53 (2001).

40) Asahi F. M., Fujii J., Suzuki K., Seo H. G., Kuzuya T., Hori M., J. Biol. Chem., 270, 21035-21039 (1995). 
41) Ghosh S., Baltimore D., Nature (London), 344, 678 - 682 (1990).

42) Geng J. G., Cell Res., 11, 85-88 (2001).

43) Mates J. M., Perez-Gomez C., Nunez de Castro I., Clin. Biochem., 32, 595-603 (1999).

44) Sarkar D., Fisher P. B., Cancer Lett., 236, 13-23 (2006).

45) Liu H., Colavitti R., Rovira II., Finkel T., Circ. Res., 97, 967—974 (2005).

46) Palozza P., Serini S., Torsello A., Di Nicuolo F., Piccioni E., Ubaldi V., Pioli C., Wolf F. I., Calviello G., J. Nutr., 133, 381-388 (2003).
47) Schreck R., Rieber P., Baeuerle P. A., EMBO J., 10, 2247-2258 (1991).

48) Jafari B., Ouyang B., Li L. F., Hales C. A., Quinn D. A., Respirology, 9, 43-53 (2004).

49) Maiuri M. C., De Stefano D., Di Meglio P., Irace C., Savarese M., Sacchi R., Cinelli M. P., Carnuccio R., Naunyn Schmiedebergs Arch Pharmacol., 371, 457-465 (2005).

50) Bradford M. M., Anal. Biochem., 72, 248-254 (1976). 